\title{
Binns Chapel: The Little White Church and the Westward Movement
}

\author{
Edited by Walter F. Peterson
}

Charles R. Binns, son of Henry Clay Binns, wrote this story of his father's chapel. Mr. Peterson, who is chairman of the Social Science Division of Milwaukee Downer College and a great nephew of C. R. Binns, found the manuscript and edited it for the AnNals.

Henry Clay Binns, 1842-1918, settled in western Iowa in 1854, about eight miles south of Red Oak in Page County. Just one year before, the first sermon had been preached in Clarinda, the county seat, and in 1858 the first church was built there.

Methodism prospered and grew in the county, for there were 27 Methodist societies by 1890 with a total membership of 1,814 . These were small, struggling congregations for they consisted on the average, of only 67 members each. However, in those days of poor transportation, there were dedicated Methodist clergy given to circuit riding, so many small congregations could and did spring up.

In 1875, when the people concerned in the following article proposed to form their own congregation, Henry Clay Binns was the largest landowner in the area. He was not a member, but he gave much to the church and the chapel was erected on his land.

The story of Binns Chapel, which served as a house of worship for only a decade, 1875 to 1885, must be typical of hundreds of little white churches erected by people involved in the westward movement.

Few people have ever heard of the little white country church which was built by sincere and hard striving people and which once stood so majestically among the big oak trees about 40 rods from the front door of our farm house.

It seemed that the people of our community had been waiting for someone with Christian faith and leadership ability to guide them toward the better things in life, and so it developed that a kindly neighbor with a family of small 
children became the accepted leader. As a devout Christian, his first duty was to organize a Sunday School which was regularly held in the school house. Religious interest grew rapidly, resulting in the proposed building of a small church. I don't remember just why the location on our farm was chosen. Perhaps our picnic ground, under the shade of those great oak trees was an influencing factor, for it was a lovely spot.

In looking through some of my father's old personal papers recently, I found the specifications for building that little church-28x40 feet. It was a gigantic, and at times a discouraging undertaking for the people in our community, who were already heavily burdened with mortgages on their homes and other obligations. But, when the final arrangements were made and the call went out in the form of a subscription list soliciting contributions, they responded most loyally.

It is my recollection that the church organization of that district agreed to contribute a certain amount toward building the church, but even then the members found themselves facing a sizeable deficit. It was their fondest hope that the little church would be entirely free of debt at the time of its dedication. When all efforts toward raising the final payment had failed, my father, Henry Clay Binns, who was not a member but a liberal contributor, came forward and gave them his check to cover the balance due, clearing the little church of all debt. It was then named Binns Chapel.

In the days when buggies were considered a real luxury to be enjoyed by a favored few, the people of our community rode to church in their farm wagons, tied their horses to a tree, and then turned to discussing the issues of the day until the time the services were to begin. I recall that during the winter months it was my painful duty to build the fires in our church, a most tiresome task for a boy. This important position was not conferred upon me by the people, but was a directive issued by my father without compensation. Our minister seemed to have had a yen for my mother's cooking, for he always was a regular guest at our Sunday dinner table, which also meant another duty shifted to me-caring for the preacher's horse. 
During the years of my close association with our little church, I witnessed many incidents of varied sort. Many of them were of a sanctimonious nature and were worthy of deep respect; some were amusing and forgotten, but occasionally someone would quite thoughtlessly do something ridiculous that would try the patience of a saint. I recall the ignoble act of one man who, to my personal knowledge, had never been inside a church before. While the offering was being passed before him he threw a quarter into the hat, saying, "That will pay for my seat and the heat while I am here." Then there was the member who had carefully memorized three different prayers. At times he would become uncontrolably excited and combine all three prayers into one.

I remember that my aunt Marietta, a most tolerant and lovable woman, taught a Sunday School class of young boys of my own age whose youthful minds were filled with everything except Sunday School interest. In those years of scarcity, when the contributions to the missionary cause were counted in pennies, a man's hat was used in collecting the offering. A near-sighted member, an old man of careful habits, would drop a coin into the hat and invariably reach in and withdraw some change. We young boys, always alert to the unusual, reckoned that the old man put in a nickel and took out a dime.

Once just before Christmas when the holiday spirit was beginning to permeate more freely, arrangements were made to decorate the church in full gala splendor. Acting along the usual line of procedure, a committee of two men and two girls locally known for their decorative ability were chosen to do the work. For some reasons one of the girls failed to appear, leaving the trio to finish the job. As might be expected, strong rivalry was set up to gain the favor of the lone fair one. Presumably the only reason why I happened to be there at the time was because a small boy like me wasn't wanted.

If I were called upon today to classify that little congregation of years ago, with no intention of favoritism, I probably would say that the parents and older folks came expressly to worship. Perhaps I would say that the younger women and girls, dressed in their fancy frills and frocks, were there to see and be seen. Little can be said about the youngsters, the 


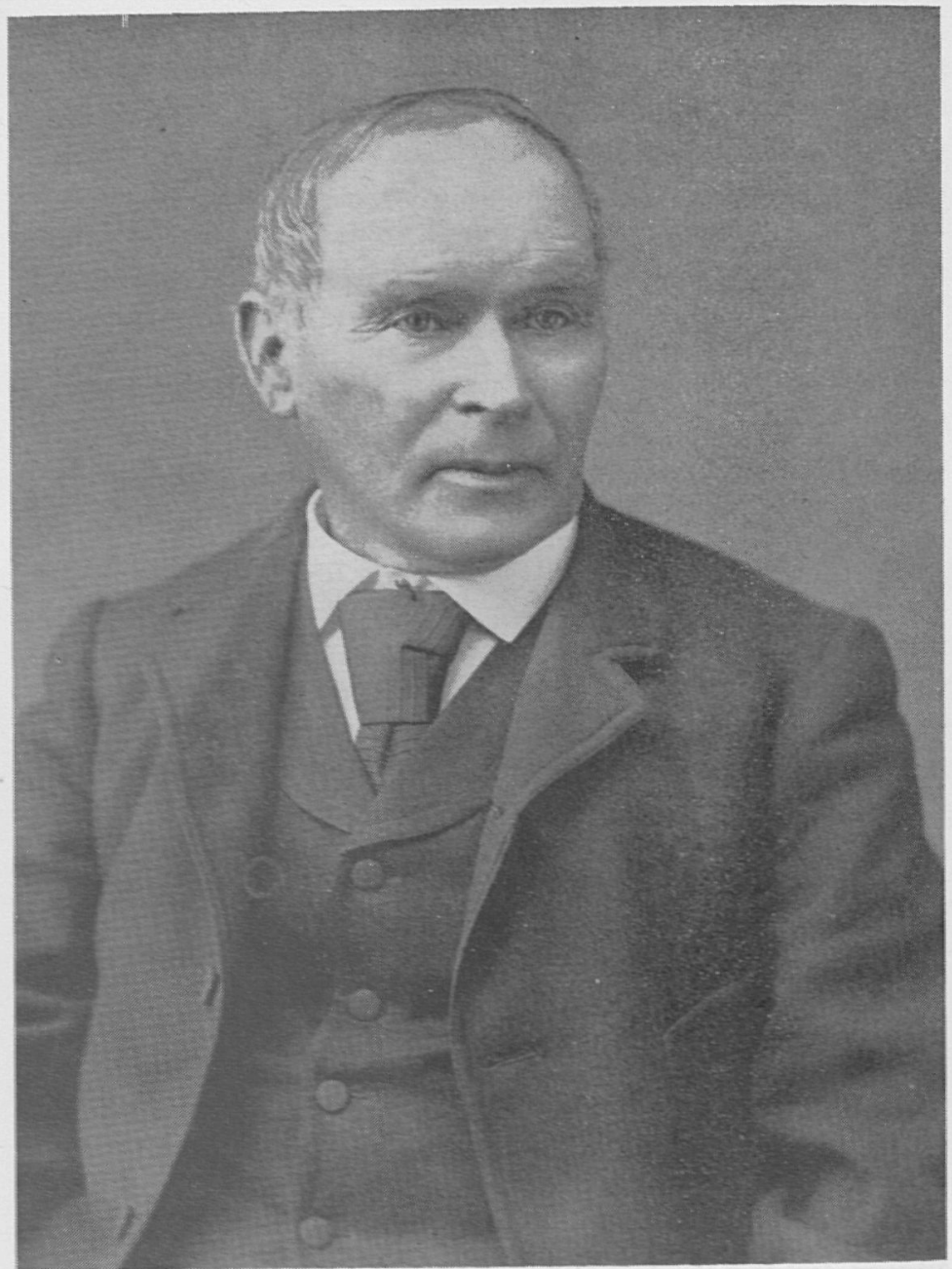

Henry Cluay Binns

boys who were always boasting of their growing strength before the other boys and were usually willing to demonstrate it. In spite of this, there existed the Divine Power over all, the desire to worship and the influences of Christian society, which really brought us together in the friendly little church.

In the course of a few years, when the broad prairies beyond the Missouri River began to beckon and settlers were 
moving on to establish new homes, many of the active members, who so faithfully had supported the church, sold their farms and moved farther west. The newcomers, the people who later were to rebuild our country, already had a church of their own.

So it was that our congregation began to dwindle, becoming less and less, and finally closing its friendly doors forever. The little country church that in the past had served our community as a religious and social center was turned over to the mercy of the timber squirrels and woodpeckers.

Later, some enterprising men and women, acting under their personal promotional interest of getting something for almost nothing, moved the church to a new location about eight miles north. Soon, after being anchored in its new location, a heavy gale totally destroyed it, scattering parts to the four winds - a tragic ending of a once beloved house of worship.

\section{Mile Walk Every Night}

Troopers Take It to Evade Guards and Check In at Night

No need for the walking test among enlisted at Fort Des Moines. They take it voluntarily, twenty miles a day.

This rapid transition from cavalry to infantry has taken place since Colonel West, commanding officer, issued orders that each trooper must show a pass to the guard on the townbound car before he can get on.

The order for a time worked a hardship on many of the soldiers, but a way to get around the colonel's order has been found.

When the men learn that they are denied a pass they run the outpost guards and walk the five miles into town, back before 11 to check in, and back to town again to end the evenings enjoyment, and finally end up at the fort for reveille at 6 in the morning.

The men are required to check in at their barracks at 11 at night, hence their appearance at the fort at the hour. If they want to go back to town again they run the guard and walk the West Ninth street road.

(Des Moines Daily News, December, 1908) 
Copyright of Annals of Iowa is the property of State of Iowa, by \& through the State Historical Society of Iowa and its content may not be copied or emailed to multiple sites or posted to a listserv without the copyright holder's express written permission. However, users may print, download, or email articles for individual use. 